that he used were the 60 -in reflector at Mt. Wilson Observatory and the 26 -in. refractor at the Naval Observatory, Washington. An account is given of his observations on cracks and clefts, the first object dealt with being the crater of Vendelinus. In 1891, T. Gwyn Elger, the first director of the Lunar Section, British Astronomical Association, observing this crater with his $8 \frac{1}{2}-i n$. Calver reflector, saw a cleft or crack running north from a small crater on the northern part of the interior, and Elger recorded this cleft later, additional confirmation being obtained by Dr. W. H. Maw's observations with his 6-in. refractor. Wilkins and other experienced observers failed to find a trace of it, and the remarkable thing is that not only did the 60 -in. telescope reveal no cleft, but where it once appeared Wilkins saw elevations. Perhaps more remarkable still is the fact that though the cleft had vanished, two new ones had opened up, one on each side of its former position. An examination of Mare Humorum with the Washington 26-in. refractor showed that the border of this plain, which had been known to be extensively cracked, was much more cracked than had been previously suspected. Five clefts seem to be new and one marking shown by the older observers as a ridge is now a cleft. These are only two instances, supported by a considerable body of evidence, and suggest that cracks are still being formed.

\section{Excavations at Kirkstall Abbey, near Leeds}

The Thoresby Society has been excavating for a number of years at Kirkstall Abbey, near Leeds, and the fifth report of the Society, covering 1954 (pp. $16+2$ plates; from the Society, Leeds ; 1955 ; 1 s.), describes an interesting find of a large earthenware crucible. The crucible is $171 \mathrm{in}$. high and $17 \frac{3}{\mathrm{in}}$. in diameter at the top, decreasing to $11 \frac{1}{8}$ in. at the base, and was used for refining copper or bronze. Metallurgical methods and processes, whether used in the Bronze Age or in later medieval times, are always of interest, and the new find adds considerably to our knowledge of how the folk of this latter period worked. A general account of metallurgical processes is also given, and this will be welcomed by students of many different periods who have not had any training in chemical studies.

\section{A Museums Calendar for British Museums and Art Galleries}

For many years the museums, art galleries and cognate institutions in Great Britain have suffered from a lack of current and reliable information concerning themselves and allied institutions. At one time and another directories have been issued, but these are costly compendiums and are soon out of date. The Museums Association has recently issued an excellent "Museums Calendar" which contains an almanac for 1955, various details of the Association, including notes on its past history, regulations for both its diploma and technical certificate, a complete list of institutional and personal members, and a list of all the museum and art galleries in Great Britain. Details of the present policy of the United Kingdom Carnegie Trustees towards museums are given, as well as particulars, with a useful map, of the regional federations. For the present issue it was only possible to collect information regarding certain overseas museums and art galleries, but in subsequent annual editions, to be issued in January, this feature will be greatly extended. Such a publication is indispensable for those working in, or associated in any way with,
British museums and art galleries. In stiff paper covers, it is published at the reasonable price of $5 s$. and can be obtained from the Museums Association, 33 Fitzroy Street, London, W.1.

\section{Distribution Maps of Scandinavian Species of Hieracium}

During the last few years of his life, Prof. Gunnar Samuelsson was engaged on a compilation of some of the main features of the plant geography of the Scandinavian Hieracium flora. To this end he had prepared distribution maps of more than a hundred species. At the time of his death in 1944 these maps were in a more-or-less complete state; but they had not been worked up or commented on in any way. This has now been done by Erik Almquist, the work being available as a publication of the Kungl. Svenska Vetenskapsakad. Handl. (Fjärde Serien, 5, No. 3; 1954). 'This monograph includes 123 maps and a short foreword and index. According to the editor, "Samuelsson's main intention seems to have been to bring to light a number of different distributive types, and to show, at the same time, how far we have come in our knowledge of the occurrence of the more important species". The commentary in the foreword on the distribution of different species and groups is brief; but a number of interesting points are made. In particular, the view is expressed that, although most species of Hieracium are in various ways favoured by cultivation, the maps nevertheless afford a fair indication of their natural distribution, certainly of the species of at least some sections of the genus. It is held that spreading of a synanthropic kind over large distances is unusual. Species of other sections, on the other hand, are moreor-less entirely associated with localities under cultivation; but the bulk of tho area's species "undoubtedly consists of endemic small species of varying age, having mostly emerged in post-glacial time".

\section{Speciation and Variation in Asexual Fungi}

IN a monograph under this title, published under the editorship of R. W. Miner, as Vol. 60, pp. 1-182 (1954), of the Annals of the New York Academy of Science, readers will find a rich collection of wellillustrated information on this important botanical topic. As Dr. K. B. Raper says in the introduction : "I do not believe that we are dealing with problems basically different from those faced by an investigator concerned with the taxonomy of microorganisms. In the so-called asexual fungi, however, these problems become particularly acute. The very fact that these organisms reproduce themselves so successfully without the intervention of sexuality at once precludes from consideration a developmental phase with attendant characteristics and structures which, if present, would normally provide the most stable features possible. In the absence of such features, we must somehow get along with what is left". The individual contributions cover a wide range of mycological themes, such as interrelationships of speciation, type preservation, and nomenclature in bacteria; variation and speciation in the genus Fusarium; the evolution of species concepts in Aspergillus and Penicillium; spontaneous and induced variation in selected stocks of the Penicillium chrysogenum series; experimental control of morphogenesis in micro-organisms; natural and cultural variation in entomogenous Fungi Imperfecti ; types of variation in Actinomycetes; variation and 